Supplemental On-line Materials for

\title{
The Diminishing Criterion Model for metacognitive regulation of time investment
}

\author{
Rakefet Ackerman \\ Journal of Experimental Psychology: General \\ http://www.apa.org/pubs/journals/xge/
}

Table S1. A full list of the problems used in Experiment 5.

\begin{tabular}{|c|c|c|c|c|}
\hline Problem & Units & $\begin{array}{l}\text { Correct } \\
\text { answer }\end{array}$ & $\begin{array}{l}\text { Misleading } \\
\text { answers }\end{array}$ & Reference \\
\hline $\begin{array}{l}\text { 1. A bat and a ball together cost } \$ 1.10 \text {. The bat costs } \$ 1.00 \text { more } \\
\text { than the ball. How much does the ball cost? }\end{array}$ & cents & 5 & 10 & $\begin{array}{l}\text { Kahneman and Frederick } \\
\text { (2002) }\end{array}$ \\
\hline $\begin{array}{l}\text { 2. If it takes } 5 \text { machines } 5 \text { minutes to make } 5 \text { widgets, how long } \\
\text { would it take } 100 \text { machines to make } 100 \text { widgets? }\end{array}$ & minutes & 5 & 100 & Frederick (2005) \\
\hline
\end{tabular}




\begin{tabular}{|c|c|c|c|c|}
\hline Problem & Units & $\begin{array}{l}\text { Correct } \\
\text { answer }\end{array}$ & $\begin{array}{l}\text { Misleading } \\
\text { answers }\end{array}$ & Reference \\
\hline $\begin{array}{l}\text { 3. In a lake, there is a patch of lily pads. Every day, the patch } \\
\text { doubles in size. If it takes } 48 \text { days for the patch to cover the entire } \\
\text { lake, how long would it take for the patch to cover half the lake? }\end{array}$ & days & 47 & 24 & Frederick (2005) \\
\hline $\begin{array}{l}\text { 4. If you flipped a fair coin } 3 \text { times, what is the probability that it } \\
\text { would land "Heads" at least once? }\end{array}$ & percent & 87.5 & $12.5,37.5$ & $\begin{array}{l}\text { Frederick (personal } \\
\text { communication, Nov. 2009) }\end{array}$ \\
\hline $\begin{array}{l}\text { 5. A frog fell into a hole } 30 \text { meters deep. Every day it climbs up } 3 \\
\mathrm{~m} \text {, but during the night it slides } 2 \mathrm{~m} \text { back down. How many days } \\
\text { will it take the frog to climb out of the hole? }\end{array}$ & days & 28 & 30 & GMAT practice book \\
\hline $\begin{array}{l}\text { 6. Apple mash is comprised of } 99 \% \text { water and } 1 \% \text { apple solids. I } \\
\text { left } 100 \mathrm{~kg} \text { mash in the sun and some of the water evaporated. Now } \\
\text { the water is } 98 \% \text { of the mash. What is the mash weight? }\end{array}$ & $\mathrm{kg}$ & 50 & 99 & $\begin{array}{l}\text { Uri Leron (personal } \\
\text { communication, Nov. 2009; } \\
\text { Attributed to Abraham } \\
\text { Arcavi) }\end{array}$ \\
\hline $\begin{array}{l}\text { 7. Jack is looking at Anne, and Anne is looking at George. Jack is } \\
\text { married, but George is not. Is a married person looking at an } \\
\text { unmarried person? A) Yes B) No C) Cannot be determined }\end{array}$ & & $\mathrm{A}$ & $\mathrm{C}$ & Stanovich (2009) \\
\hline
\end{tabular}




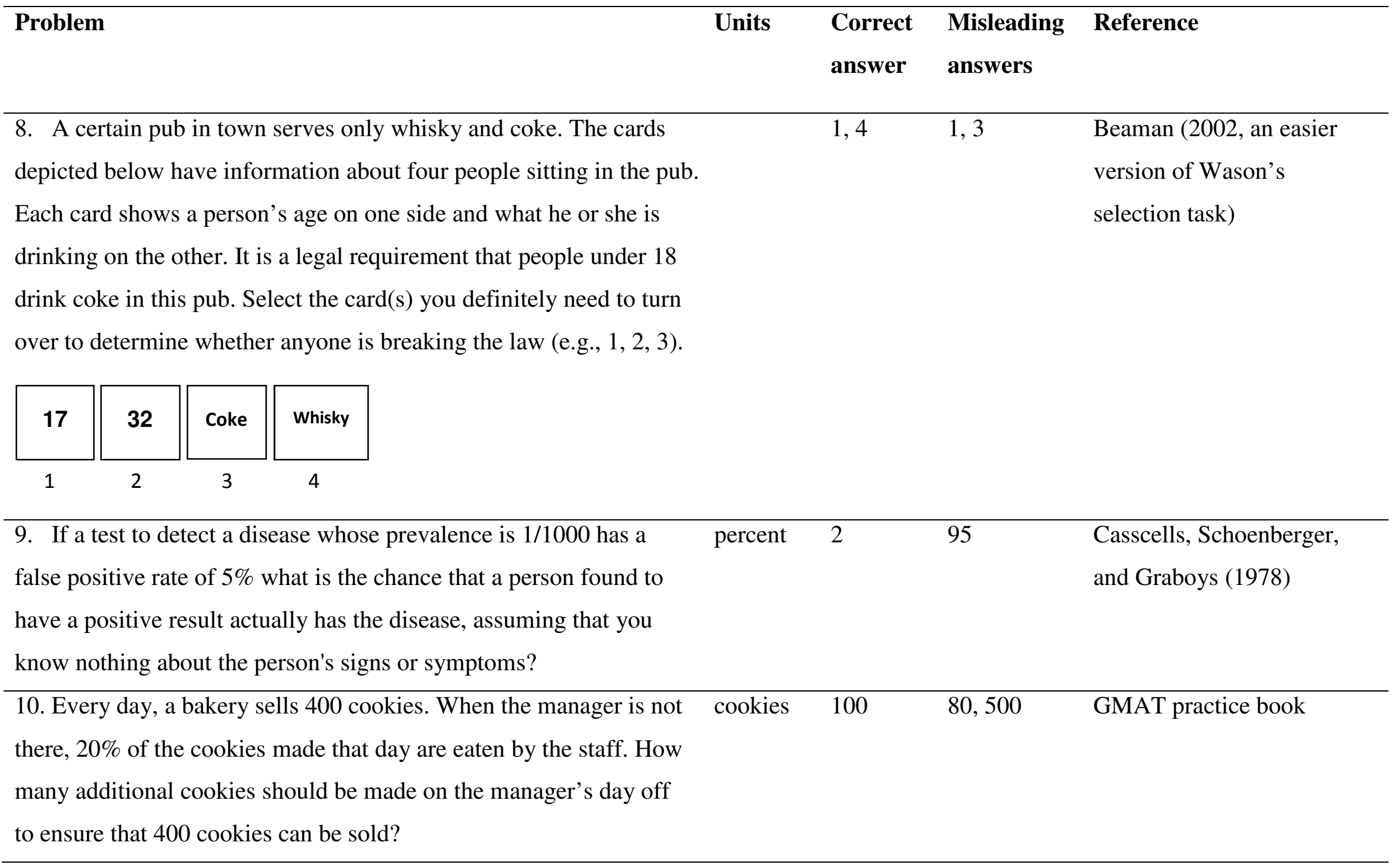




\begin{tabular}{|c|c|c|c|c|}
\hline Problem & Units & $\begin{array}{l}\text { Correct } \\
\text { answer }\end{array}$ & $\begin{array}{l}\text { Misleading } \\
\text { answers }\end{array}$ & Reference \\
\hline $\begin{array}{l}\text { 11. Steve was standing in a long line. To amuse himself he counted } \\
\text { the people waiting, and saw that he stood 38th from the beginning } \\
\text { and } 56 \text { th from the end of the line. How many people stood in the } \\
\text { line? }\end{array}$ & people & 93 & 94,92 & GMAT practice book \\
\hline $\begin{array}{l}\text { 12. Ants are walking in a line. A bad-mannered ant cuts in front of } \\
\text { the ant walking second. What is the rude ant's place in the line? }\end{array}$ & & $2^{\text {nd }}$ & $1^{\mathrm{st}}$ & GMAT practice book \\
\hline
\end{tabular}

\section{References}

Beaman, C. P. (2002). Why are we good at detecting cheaters? A reply to Fodor. Cognition, 83(2), 215-220.

Casscells, W., Schoenberger, A., \& Graboys, T. B. (1978). Interpretation by physicians of clinical laboratory results. The New England Journal of Medicine, 299(18), 999-1001.

Frederick, S. (2005). Cognitive reflection and decision making. Journal of Economic Perspectives, 19(4), 25-42.

Kahneman, D., \& Frederick, S. (2002). Representativeness revisited: Attribute substitution in intuitive judgment. In T. Gilovich, D. Griffin \& D. Kahneman (Eds.), Heuristics and biases: The psychology of intuitive judgment (pp. 49-81). New York: Cambridge University Press.

Stanovich, K. E. (2009). Rational and irrational thought: The thinking that IQ tests miss. Scientific American Mind, 20(6), 34-39. 